\title{
Failure to Disinfect
}

National Cancer Institute

\section{Source}

National Cancer Institute. Failure to Disinfect. NCI Thesaurus. Code C63179.

Failure to properly disinfect the device during reprocessing. 